\title{
Commentary: Sometimes two wrongs do make a right
}

\author{
Ian A. Makey, MD, and Kevin P. Landolfo, MD
}

\author{
From the Department of Cardiothoracic Surgery, Mayo Clinic, Jacksonville, Fla. \\ Disclosures: Authors have nothing to disclose with regard to commercial support. \\ Received for publication Sept 20, 2018; accepted for publication Sept 21, 2018; available ahead of print Nov 2 , \\ 2018. \\ Address for reprints: Kevin P. Landolfo, MD, Department of Cardiothoracic Surgery, Mayo Clinic-Florida, 4500 \\ San Pablo Rd, Jacksonville, FL 32224 (E-mail: landolfo.kevin@ mayo.edu). \\ J Thorac Cardiovasc Surg 2019;158:e171 \\ 0022-5223/ $\$ 36.00$ \\ Copyright (C) 2018 by The American Association for Thoracic Surgery \\ https://doi.org/10.1016/j.jtcvs.2018.09.095
}

Complications following cardiac surgery remain an important topic of clinical focus. For example, the technique of sternal closure has been addressed in several hundred reports over the past several decades. ${ }^{1}$ Although the most effective technique of sternal closure remains ill-defined, coaptation of sternal edges and layered closure of soft tissue is required. Heuts and colleagues ${ }^{2}$ report an interesting case of what can happen if these elements are not achieved and a creative solution to the mistakes. On POD\#5 after a mitral valve repair for infective endocarditis, workup for respiratory insufficiency and hypotension by chest radiograph revealed pneumopericardium. This was caused by sternal and wound separation at the lower aspect of the sternum. ${ }^{2}$ Negative intrathoracic pressure sucked air through a 1way-valve-like wound tract. Follow-up computed tomography scan demonstrated a dramatic pneumopericardium and substantial pneumoperitoneum. Pneumopericardium can cause cardiac tamponade and hemodynamic compromise in rare circumstances. ${ }^{3}$ Although this patient became hypotensive, the authors suggest that profound tamponade was avoided due to a secondary opening between the pericardium and peritoneum that allowed decompression. The complication was identified and treated successfully by percutaneous needle decompression of the pericardial space and reapplication of an occlusive dressing over the incision. The patient recovered uneventfully and required no further reintervention after 2 years of follow-up.

This report highlights the attention to detail required for the performance of safe and effective cardiac surgery. Sternotomy remains the most commonly used incision to perform a variety of cardiac surgical procedures. Because sternal closure is routine, it is often performed by someone other than the primary surgeon, potentially leading to

\section{References}

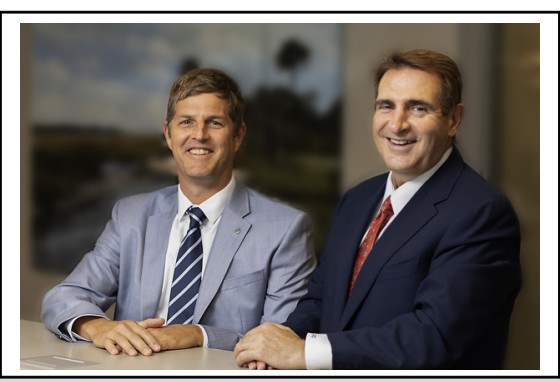

lan A. Makey, MD, and Kevin P. Landolfo, MD

Central Message

Sternal closure is routine, but still an essential part of successful cardiac operations.

See Article page e169.

suboptimal closure. Inadvertent entry into the abdominal cavity, which can occur during opening, is usually closed with deep fascial sutures at the end of the procedure. Inadequate closure of the fascia, in this case, may have prevented a life-threatening cardiac tamponade. Although this patient was successfully treated with an occlusive dressing application, more aggressive treatment with reoperation and repair of the partial sternal dehiscence would have been our preferred approach. An infectious complication was certainly a possibility because there was clearly communication between the skin and the edges of the sternum. Moreover, layered tissue reapproximation and rigid bone fixation are important elements to prevent delayed wound healing and wound infections. ${ }^{4}$

A successful cardiac repair can be derailed by mistakes at any time during the operation. Fortunately, in this report 2 mistakes may have prevented a worse outcome.

1. Veeramachaneni N. Optimal sternal closure technique-still evolving. J Thorac Cardiovasc Surg. 2018;156:187.

2. Heuts S, al Khoury F, Sardari Nia P. Lighthearted: pneumopericardium after mitral valve repair. J Thorac Cardiovasc Surg. 2019;158:e169-70.

3. Cummings RE, Wesley RL, Adams DH, Lowe JE. Pneumopericardium resulting in cardiac tamponade. Ann Thorac Surg. 1984;37:511-8.

4. Lazar HL, Salm TV, Engelman R, Orgill D, Gordon S. Prevention and management of sternal wound infection. J Thorac Cardiovasc Surg. 2016;152:962-72. 